\title{
Changes in mountain glaciers and ice caps during the 20th century
}

\author{
Atsumu OHMURA \\ Institute for Atmospheric and Climate Science, Swiss Federal Institute of Technology (ETH), CH-8057, Zürich, Switzerland
} E-mail: atsumu.ohmura@env.ethz.ch

\begin{abstract}
The global mass balance of the glaciers outside Greenland and Antarctica is evaluated based on long-term mass-balance observations on 75 glaciers. The cause of the mass-balance change is investigated by examining winter and summer balances from 34 glaciers. The main finding is a common development in mass-balance changes shared by a number of glaciers separated by large distances and climatic conditions. The average mass balance for the second half of the 20th century was negative at -270 to $-280 \mathrm{~mm} \mathrm{a}^{-1}$. The negative mass balance was found to be intensified at $-10 \mathrm{~mm} \mathrm{a}^{-2}$. Increasing summer melt plays a dominant role in determining the long-term trend in mass balance. During the same period the mean winter mass balance increased slightly, indicating an acceleration $\left(3 \mathrm{~mm} \mathrm{a}^{-2}\right)$ of the hydrological cycle. On some Scandinavian glaciers the mean mass balance was not only positive but its tendency was accelerating. This trend is due to the strong precipitation increase in the last four decades. The melt/temperature relationships for the two warmer periods in the 20th century, one centred around the 1940s and the other ongoing, are different. Reduced melt in the modern warm period, in comparison with the earlier warm phase of the 1940s, is caused by the global dimming which reduced the solar radiation at the Earth's surface during the second half of the 20th century.
\end{abstract}

\section{INTRODUCTION}

The entire cryosphere, seasonal snow cover, sea ice, glaciers and permafrost collectively cover $70 \times 10^{6} \mathrm{~km}^{2}$ or $14 \%$ of the Earth's surface. The total ice volume of the cryosphere is estimated at $33 \times 10^{6} \mathrm{~km}^{3}$ (Ohmura, 2004). All these cryosphere components have shown significant changes during the 20th century. The objective of this paper is to present the results of a mass-balance analysis of mountain glaciers and ice caps of the world. The total area and ice volume of glaciers are about $15.9 \times 10^{6} \mathrm{~km}^{2}$ and $33.1 \times 10^{6} \mathrm{~km}^{3}$, respectively. The surface areas and volumes of the cryosphere and its individual components have been recently reevaluated. The history of the evaluations, their accuracy and the present estimations are detailed by Ohmura (2004).

The total area and volume of mountain glaciers and ice caps outside Greenland and Antarctica are $512 \times 10^{3} \mathrm{~km}^{2}$ and $56 \times 10^{3} \mathrm{~km}^{3}$, respectively (Ohmura, 2004). Glaciers in this category occupy only $3.2 \%$ of the glacier surface and $0.17 \%$ of total glacier ice volumes. The total water equivalent of the ice locked in these glaciers corresponds to $15 \mathrm{~cm}$ in sea level (Ohmura, 2004).

The mass balance of mountain glaciers has often been compiled and evaluated for specific regions (Létreguilly, 1984; Oerlemans, 2001). Meier (1984) calculated the mass balance of the glaciers in this category globally for the period 1900-61 and discovered that in the decadal to century scale these glaciers play an important role in a global hydrological cycle at least comparable to the Greenland ice sheet. He combined the mass-balance observations and meteorological estimations of mass balance. This approach was sound, as many regions did not have mass-balance observations, and existing records were short. Later, Dyurgerov and Meier (1997, 2005), Braithwaite (2002), Dyurgerov and others (2002) and Ohmura (2004) developed mass-balance investigations based on a global-scale database.

It remains to be clarified how annual mass-balance change is caused. The important question is how winter and summer mass balances determined the total annual mass balance during the 20th century. The present paper attempts to evaluate the global mass balance of the mountain glaciers and ice caps based solely on the observed mass balances, without using meteorological estimations. For this purpose, the global mass-balance data of mountain glaciers and ice caps were assembled. An effort was made to secure separate winter and summer balance observations. This approach is necessary because the objective of the present paper is to identify the cause of the mass-balance changes. To investigate causes of massbalance change requires analysis of both winter and summer mass balances, each reflecting very different processes. The winter mass balance is to a great extent due to the winter solid precipitation. Summer mass balance is mostly a matter of melting for which air temperature is the most influential factor. The main focus is on the second half of the 20th century, especially the period 1960-2000, when more observations are available. This relatively short period is important as it includes the initial cooling period when more than half of the Alpine glaciers were advancing, and the subsequent rapid warming period with more than $90 \%$ of glaciers retreating. The present work combined with Meier (1984) will cover the entire 20th century. Further, causes of the mass-balance variation for the 20th century are elucidated, based on longer mass-balance series, highaltitude meteorological observations and long-term records of radiation.

\section{DATABASE FOR WINTER, SUMMER AND ANNUAL MASS BALANCE}

In order to analyze current mass-balance variation, a new database of annual and seasonal (winter and summer) mass balances was made. This rather laborious approach had to be taken because the existing global datasets of mass balance are biased for annual balances, and the collections with winter and summer mass balances were insufficient. It was necessary to make the analysis based solely on measured 


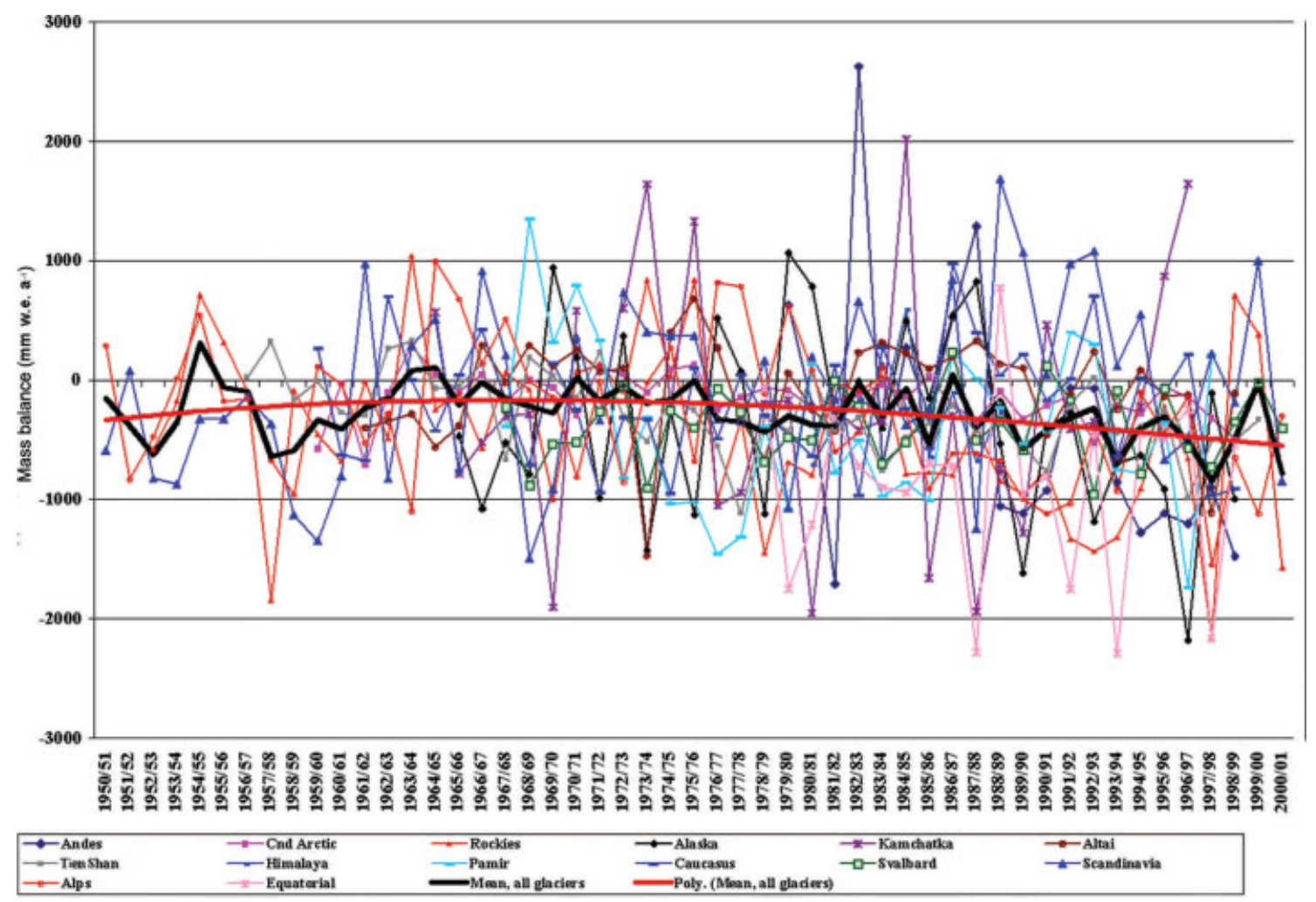

Fig. 1. Annual mass balances of 14 regions of the world for the second half of the 20th century. These regions cover $350 \times 10^{3} \mathrm{~km}^{2}$, representing $68 \%$ of the total area covered by glaciers outside Greenland and the Antarctic. In addition to the 14 regions, the area-weighted mean, plotted in a thick black line, indicates that the global mass balance was almost always negative. The mass balance came closest to zero during the period from the late 1960s to the early 1970s. During the last 30 years of the 20th century the negative mass balance has been growing at a mean rate of $-10 \mathrm{~mm} \mathrm{a}^{-2}$, reaching $-18 \mathrm{~mm} \mathrm{a}^{-2}$ at the end of the century.

seasonal mass balances, without involving meteorological estimations of mass balance. When considering the causes of the mass-balance change, it is meaningless just to analyze the annual mass balance or to use the estimations that are usually based on meteorological data. Meteorological data should be used only after observational mass balances are established. The sources of the winter and summer mass-balance data are Kasser (1967, 1973), Müller (1970), Haeberli (1985), Haeberli and Müller (1988), Haeberli and Hoelzle (1993), Haeberli and others (1998), Kjøllmoen (1998, 2000, 2001, 2003), Kjøllmoen and others (1999), Dyurgerov and others (2002), R.J. Braithwaite (personal communication, 2005), L.N. Braun (personal communication, 2005), G. Kappenberger (personal communication, 2005), H. Müller (personal communication, 2005) and C. Vincent (personal communication, 2005). An analysis of the annual mass balance is presented first, followed by a presentation of the seasonal mass balances and the interpretation.

\section{ANNUAL MASS BALANCE}

There are about 40 glaciers on which annual mass-balance observations are currently carried out with at least 30 years of continuous records. When historical data are considered, there are more than 150 glaciers where annual mass balance has been measured for shorter periods. The author selected 75 glaciers from the current and recent observations that are considered to provide mean mass-balance conditions and trends for the second half of the 20th century.
The world is divided into 14 geographical regions: the Andes (5 glaciers), the Rocky/Coastal/Cascade/Olympic Mountains (8), Canadian Arctic (5), Alaska (2), Kamchatka (1), Altai (4), Himalaya (3), Tien Shan/Dzhungariya (13), Pamir (1), Caucasus (6), Svalbard (3), Scandinavia (9), Alps (14) and Equatorial/Tropics (1). The regional mass balances were obtained by arithmetically averaging the annual mass balances of the selected glaciers. The glacier annual mass balances of the 14 regions are presented in Figure 1. Several glaciers have mass-balance records starting before 1952/53. Although these are important data for local conditions, they were not used in the present section, as their global representativeness is unknown. These longer records will be used later for understanding the relationship between the mass-balance change and the climate. Further, the area-weighted mean was calculated to estimate the global mean. The total area considered is $350 \times 10^{3} \mathrm{~km}^{2}$, or $68 \%$ of the total surface area of the glaciers in this category.

The most important result is that all regions shared certain long-term changes, despite large distances and significantly different climatic conditions separating them (Ohmura, 2004). The spatial variation of annual mass balances in the Alps was found to have a radius of $200-300 \mathrm{~km}$ with a significant autocorrelation (Chen, 1991). The area of similar mass balance becomes larger over a longer timescale. This aspect will be treated elsewhere. The mean glacier mass balance was negative in all regions except Scandinavia for the second half of the 20th century. It appears the negative mass-balance trend started globally in the early 1960s. The global area-weighted mean mass balance for the 50 year 
Table 1. Winter, summer and annual mass balance for observed regions. Columns (2-9) refer to the glaciers with both seasonal and annual mass-balance observations, while columns (10-13) refer to the glaciers only with annual mass-balance observations

\begin{tabular}{|c|c|c|c|c|c|c|c|c|c|c|c|c|}
\hline Region & $\begin{array}{c}\text { Winter } \\
\text { balance, } \\
B_{\mathrm{w}} \\
(2)\end{array}$ & $\begin{array}{l}B_{\mathrm{w}} \\
\text { trend } \\
\text { (3) }\end{array}$ & $\begin{array}{c}\text { Summer } \\
\text { balance, } \\
B_{\mathrm{s}} \\
(4)\end{array}$ & $\begin{array}{c}B_{\mathrm{s}} \\
\text { trend } \\
\\
(5)\end{array}$ & $\begin{array}{c}\text { Annual } \\
\text { balance, } \\
B_{\mathrm{n}} \\
(6)\end{array}$ & $\begin{array}{c}B_{\mathrm{n}} \\
\text { trend } \\
\end{array}$ & $\begin{array}{c}\text { Num- } \\
\text { ber of } \\
\text { glaciers } \\
\text { (8) }\end{array}$ & $\begin{array}{l}\text { Period } \\
\text { of data }\end{array}$ & $\begin{array}{c}\text { Annual } \\
\text { balance 2, } \\
B_{2} \\
(10)\end{array}$ & $\begin{array}{l}B_{2} \\
\text { trend } \\
(11)\end{array}$ & $\begin{array}{c}\text { Period } \\
\text { of data } \\
\text { (12) }\end{array}$ & $\begin{array}{c}\text { Number } \\
\text { of } \\
\text { glaciers } \\
(13)\end{array}$ \\
\hline $\begin{array}{l}\text { Rocky, Coastal, } \\
\text { Olympic, Cascade Mtns }\end{array}$ & 2282 & 2 & -2723 & -15 & -441 & -14 & 6 & 1958/59-1999/2000 & -580 & -15 & 1952/53-1999/2000 & 8 \\
\hline Canadian Arctic & 151 & 0 & -239 & -8 & -134 & -7 & 3 & 1962/63-1999/2000 & -159 & -4 & 1959/60-1999/2000 & 5 \\
\hline Alaska & 1729 & 4 & -2151 & -23 & -368 & -12 & 2 & 1965/66-1998/99 & -368 & -15 & 1965/66-1999/2000 & 2 \\
\hline Kamchatka & 3333 & -7 & -3641 & -6 & -216 & -15 & 1 & 1972/73-1994/95 & -255 & -6 & 1964/65-1996/97 & 1 \\
\hline Altai & 947 & -9 & -807 & 1 & -82 & -9 & 3 & 1976/77-1998/99 & -82 & -6 & 1961/62-1999/2000 & 4 \\
\hline $\begin{array}{l}\text { Tien Shan/ } \\
\text { Dzhungariya }\end{array}$ & 622 & -11 & -913 & -1 & -267 & -12 & 5 & 1956/57-1999/2000 & -269 & -13 & 1956/57-1999/2000 & 13 \\
\hline Pamir & 1424 & 4 & -1790 & -14 & -384 & -13 & 1 & 1967/68-1997/98 & -409 & -14 & 1967/68-1997/98 & 1 \\
\hline Caucasus & 2411 & 13 & -2562 & -12 & -149 & -2 & 1 & 1967/68-1997/98 & -203 & -1 & 1959/60-1999/2000 & 6 \\
\hline Svalbard & 691 & 0 & -1081 & 2 & -382 & 3 & 2 & 1967/68-1999/2000 & -386 & 4 & 1952/53-1999/2000 & 3 \\
\hline Scandinavia & 1907 & 16 & -1846 & -5 & 93 & 10 & 8 & $1962 / 63-1999 / 2000$ & 90 & 17 & $1962 / 63-1999 / 2000$ & 9 \\
\hline Alps & 1369 & 5 & -1701 & -39 & -332 & -32 & 2 & 1965/66-1999/2000 & -291 & -16 & 1952/53-1999/2000 & 14 \\
\hline Andes & & & & & & & & & -349 & -38 & 1979/80-1999/2000 & 5 \\
\hline Himalaya & & & & & & & & & -319 & -52 & 1980/81-1989/91 & 3 \\
\hline Equatorial/Tropics & & & & & & & & & -903 & -9 & 1978/79-1998/99 & 1 \\
\hline $\begin{array}{l}\text { Area-weighted } \\
\text { global mean }\end{array}$ & 930 & 3 & -1205 & -13 & -275 & -10 & 34 & & -279 & -8 & & 75 \\
\hline
\end{tabular}

Notes: Annual balance 2 includes those glaciers only with annual balance. The trend is defined as $\mathrm{d} B / \mathrm{d} t$, so a positive trend in $B_{\mathrm{w}}$ means an increase in winter balance, while a negative trend in $B_{\mathrm{s}}$ indicates an increase in loss.

period $1951 / 52$ to $1999 / 2000$ is $-279 \mathrm{~mm} \mathrm{a}^{-1}$. The mean mass balance for 35 years of higher-quality observations (1965/66-1999/2000) excluding the Andes, the Himalaya and the Equatorial/Tropics is $-275 \mathrm{~mm} \mathrm{a}^{-1}$. The mean mass balance over the past half-century is most likely between -270 and $-280 \mathrm{~mm} \mathrm{a}^{-1}$. During the same period, the global area-weighted mean equilibrium-line altitude (ELA) rose at a rate of $4 \mathrm{~m} \mathrm{a}^{-1}$. Considering that the total area of mountain glaciers and ice caps is $512 \times 10^{3} \mathrm{~km}^{2}$, a rough estimate of the total discharge from glaciers in this category for the corresponding period is $140 \mathrm{~km}^{3} \mathrm{a}^{-1}$, or $0.4 \mathrm{~mm} \mathrm{a}^{-1}$ in sea-level equivalent. The present evaluation together with that of Meier (1984) gives a total sea-level rise caused by glaciers outside Greenland and Antarctica during the 20th century of $43 \mathrm{~mm}$. The present analysis further shows that the global glacier mass balance is not only negative but its trend is increasing. The linear trends for the two means (arithmetic and area-weighted means) give very similar gradients, about $-10 \mathrm{~mm} \mathrm{a}^{-2}$. This increase is due to a great extent to large losses in the 1990s. The last decade of the 20th century saw a global mean mass balance of $-422 \mathrm{~mm} \mathrm{a}^{-1}$, corresponding to a sea-level equivalent of $0.6 \mathrm{~mm} \mathrm{a}^{-1}$. This is almost equal to the sum of the preceding two decades. Regionally, the largest loss was observed from the Equatorial region, represented by a single glacier, Lewis Glacier, with a mass balance of $-903 \mathrm{~mm} \mathrm{a}^{-1}$. A small gain was found on Scandinavian glaciers, where the mean balance was $90 \mathrm{~mm} \mathrm{a}^{-1}$. The regional mean showed an increase of $1 \mathrm{~mm} \mathrm{a}^{-2}$. Since this is the only region with such unusual features, it is discussed later in greater detail.

\section{WINTER, SUMMER AND ANNUAL MASS BALANCE}

There are presently only about 30 glaciers where seasonal mass balance is observed. There are four more glaciers where observations have been terminated only recently. The results of the seasonal mass balances for the 34 glaciers in the 11 regions are summarized in Table 1 . The 11 regions cover a wide range of climate, from the extremely maritime climate of Kamchatka to a very dry region in the Canadian Arctic. The mass loss ranges from $-441 \mathrm{~mm} \mathrm{a}^{-1}$ in the North American mountain ranges to a slight positive balance of $93 \mathrm{~mm} \mathrm{a}^{-1}$ in Scandinavia. Comparison of the annual balance of these 34 glaciers against the 75 glaciers with only annual balance data indicates that this small number of glaciers simulate the mass-balance conditions of all glaciers treated in the previous section well. In all regions except for Scandinavia and Svalbard the summer melt was intensified during the period. The area-weighted global mass balance for the 30 year period is presented in Figure 2. On the global average, the glaciers exhibited annual accumulation and ablation of about $1 \mathrm{~m}$ w.e., with a slightly negative mass balance for the second half of the 20th century. Further, the negative annual mass balance was becoming more negative, due to the increasing ablation in summer, while the winter accumulation has slightly increased. The rate at which ablation increased during the last 35 years of the 20th century was $-13 \mathrm{~mm} \mathrm{a}^{-2}$ and this was the major component in the annual mass balance becoming more negative at a rate of $-10 \mathrm{~mm} \mathrm{a}^{-2}$. Since the global mean temperature equivalent of melt is about $2 \times 10^{-3} \mathrm{~K} \mathrm{~mm}^{-1}$ a (Ohmura and others, 1996; Braithwaite and others, 2002; Kuhn, 2004), the present melt acceleration implies a temperature increase of $0.7 \mathrm{~K}$ over the past 35 years. This value compares very well with the global temperature increase of $0.6 \mathrm{~K}$ for JuneAugust for the period 1970-97 by Jones and others (1999). These values represent the mean condition for the 35 year period. A detailed look at the time series shows a variable development even in this rather short period. During the 1960s and 1970s, the global mass balance was steady at about $-200 \mathrm{~mm} \mathrm{a}^{-1}$. During the early 1980 s it came even 


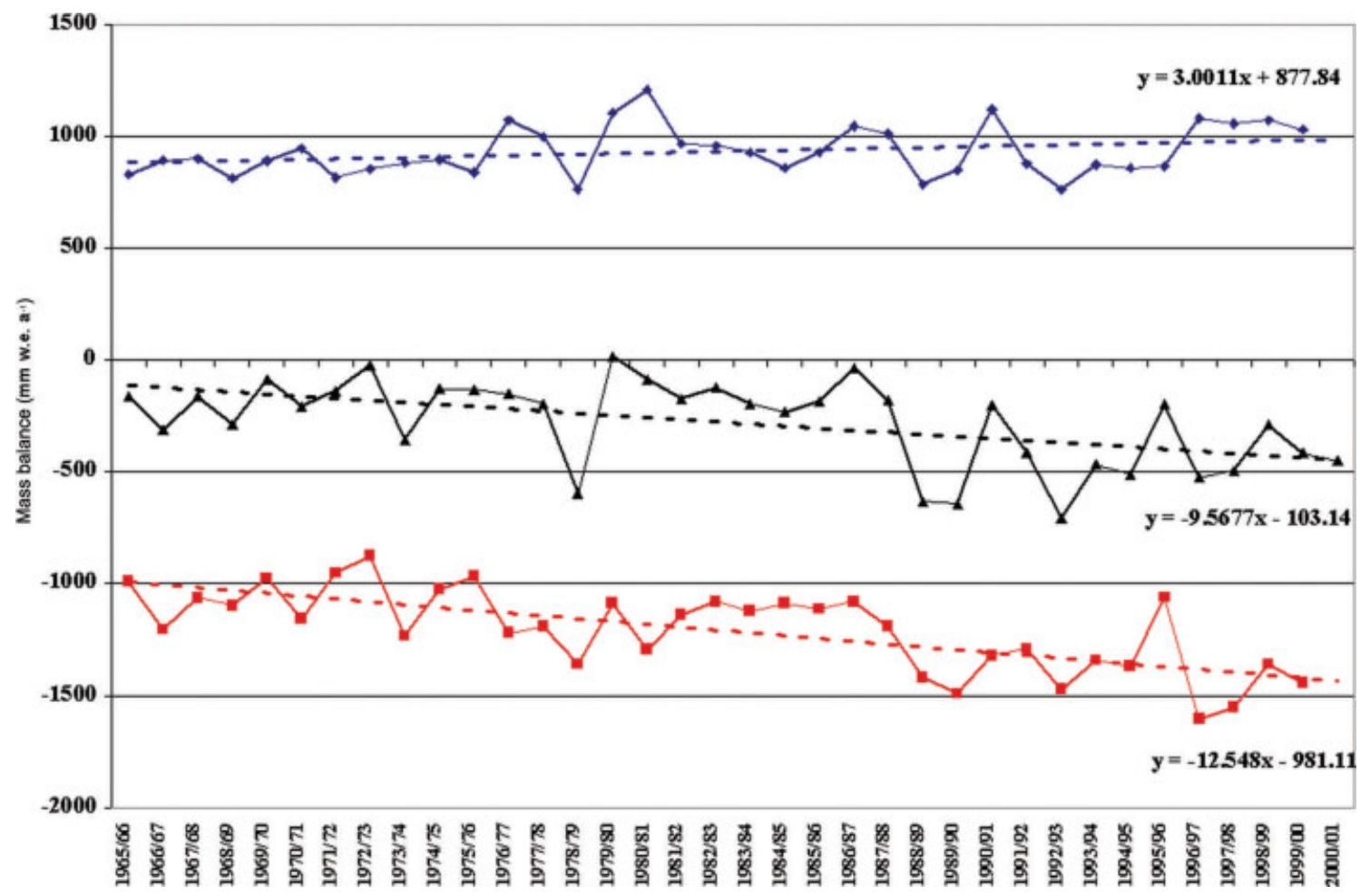

Fig. 2. Global mean area-weighted annual and seasonal mass balance of 11 regions for the period 1965/66-2000/01. From the original 14 regions in Figure 1, the Equatorial/Tropical region, the Andes and the Himalaya have been dropped due to lack of observations. The figure shows mass loss becoming more negative at a rate of $-10 \mathrm{~mm} \mathrm{a}^{-2}$, which is mostly caused by melt $\left(-13 \mathrm{~mm} \mathrm{a}^{-2}\right)$, as the accumulation rate was slightly accelerated at $3 \mathrm{~mm} \mathrm{a}^{-2}$. Blue line: winter balance; red line: summer balance; black line: annual balance. Linear regressions are given next to the corresponding curves.

nearer to equilibrium until it was followed by a period of sudden and large mass loss in the late 1980s, which continues to the present. These decadal fluctuations require a much longer time series for the full analysis and will be discussed later.

\section{GLACIERS IN SCANDINAVIA}

While most regional mass-balance trends fit the global conditions presented above, the glaciers in Scandinavia often appear to be an exception. This point deserves more detailed analysis. First of all, these glaciers are used as an argument for discounting the impact of ongoing global warming. Secondly, the quality and length of the massbalance observations in Norway and Sweden are extremely good, so that more detailed examinations are possible. In Figure 3 the mean annual and seasonal mass balances for eight Scandinavian glaciers are presented.

Four out of eight glaciers indicate positive mass balance for the last 40 years of the 20th century. They are located near the Atlantic coast and are characterized by high winter accumulation. These glaciers registered a significant increase in accumulation during the last 40 years of the 20th century. Most of these glaciers were at equilibrium during the 1960s and moved into a slightly positive mass-balance regime starting in the early 1970 s. The mean accelerating rate of the annual mass balance for the last 40 years of the 20th century was $10 \mathrm{~mm} \mathrm{a}^{-2}$, influenced by a strong increase in accumulation $\left(16 \mathrm{~mm} \mathrm{a}^{-2}\right)$. Although ablation also increased at $5 \mathrm{~mm} \mathrm{a}^{-2}$, the accumulation increase was much faster. Examining individual glaciers, it was found that about half of the glaciers exhibited a decreasing trend of melt over this period. The linear trend, however, depends on the period chosen. The last two decades of the 20th century showed a different course. For the period 1981-2000, an increasing trend of ablation was observed on all glaciers, except Nigardsbreen which showed no significant increase of melt. The ablation trend on Nigardsbreen, however, changed into a rapid increase in the last 10 years of the 20th century. The average melt increase for the eight Scandinavian glaciers for the last 20 years of the 20th century was $15 \mathrm{~mm} \mathrm{a}^{-2}$, which is very close to the global trend. In the mid-1990s, the mean mass balance of these Scandinavian glaciers started to become negative. Therefore, it was the rapid increase in accumulation that created the trend during the last 40 years of the 20th century, offsetting the influence of the warming. During the last 10 years of that period, however, Scandinavia joined the rest of the world in experiencing an increase in ablation and loss of mass. The increase in melt after 1997 is especially large. An increasing winter precipitation trend for Scandinavia under the enhanced greenhouse effect has been predicted by some recent global climate model (GCM) experiments (Roeckner and others, 1999).

\section{LONG-TERM VARIATION OF MASS BALANCE AND CLIMATE}

The three longest mass-balance series in the world, those of Storglaciären, Storbreen and Glacier de Sarennes, are all located in Europe and cover more than half a century. They offer a rare opportunity to examine how mass balance is related to the climate, especially when the climate is in transition. Figure 4 shows the mean winter, summer and 


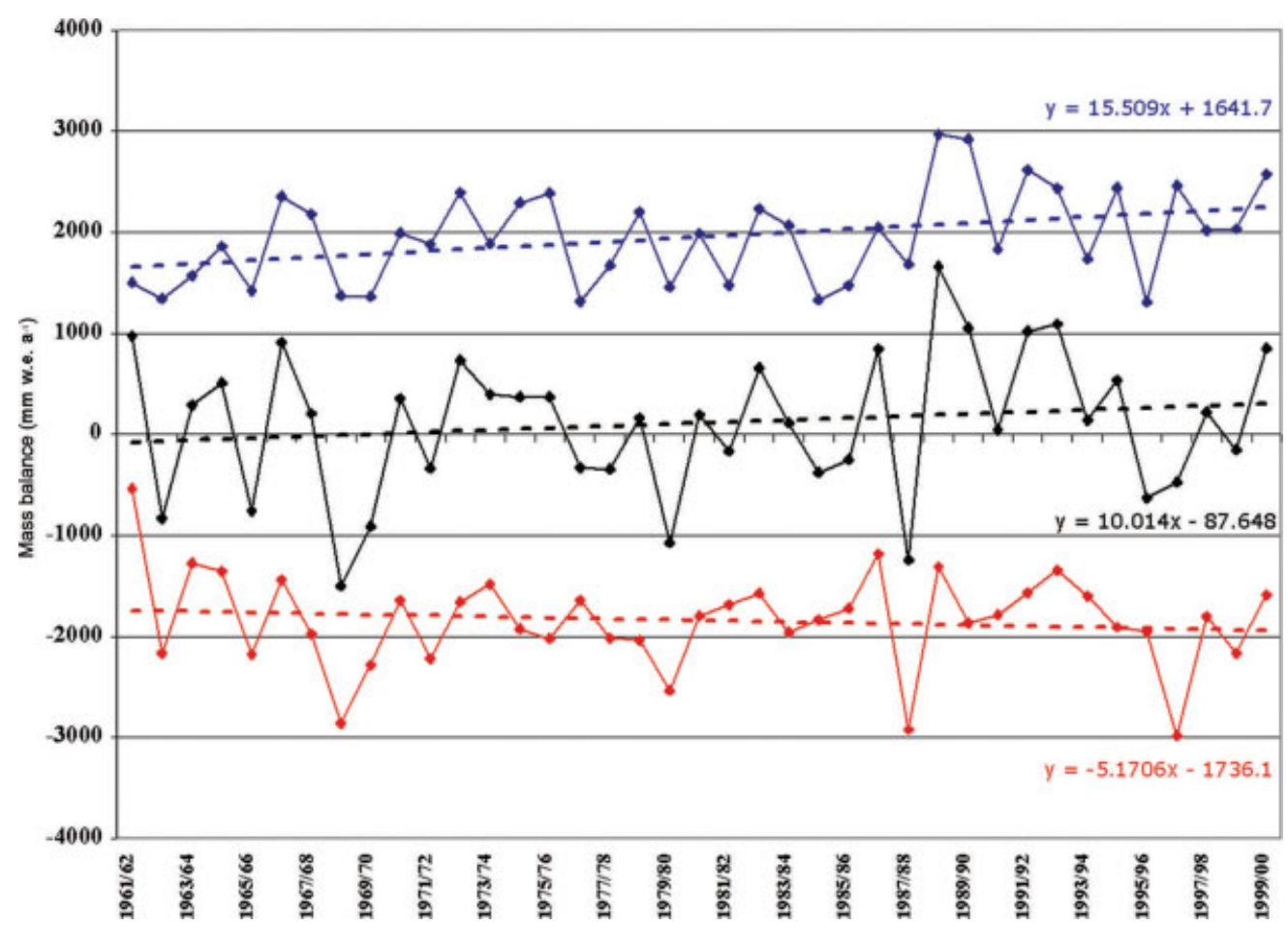

Fig. 3. The mean annual and seasonal mass balance of eight glaciers in Scandinavia for the period 1961/62-1999/2000. Blue line: winter balance; red line: summer balance; black line: annual balance.

annual mass balance of the three glaciers. The negative annual mass balance decreased in magnitude towards the 1970 s and 1980s. The abrupt beginning of the large mass loss in the early 1990s is clearly depicted. More important, however, is the similar course taken by the winter and summer mass balances. In a phase of larger melt, such as the 1940 s to early 1950 s and recently after 1990, the accumulation also tended to be larger. This is glaciological evidence

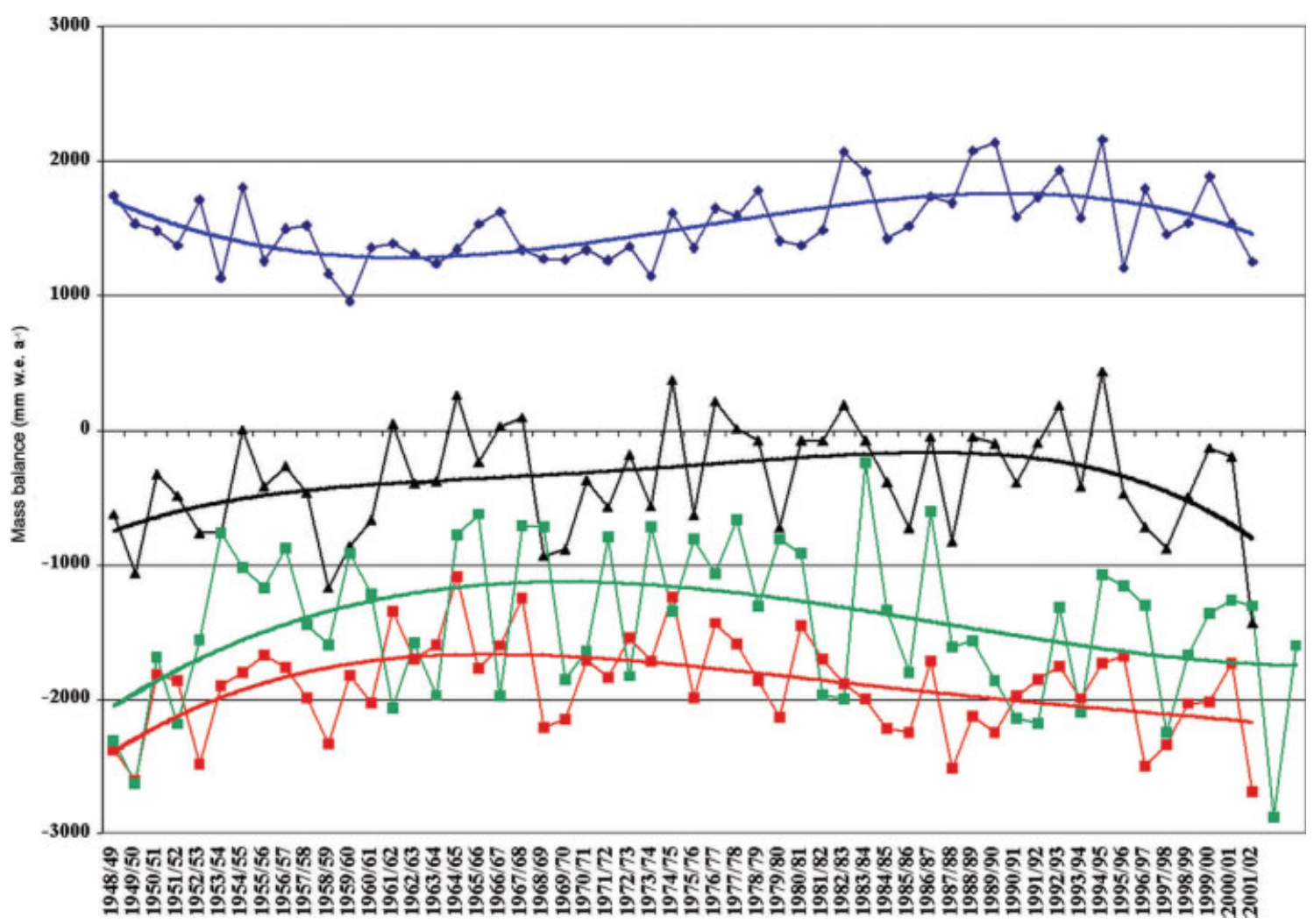

Fig. 4. Mean winter (blue line), summer (red line) and annual (black line) balances for the glaciers with the three longest mass-balance series in the world, Storglaciären, Storbreen and Glacier de Sarennes, for the 54 year period 1948/49-2001/02. Summer balance of Claridenfirn (green) is added for comparison. 


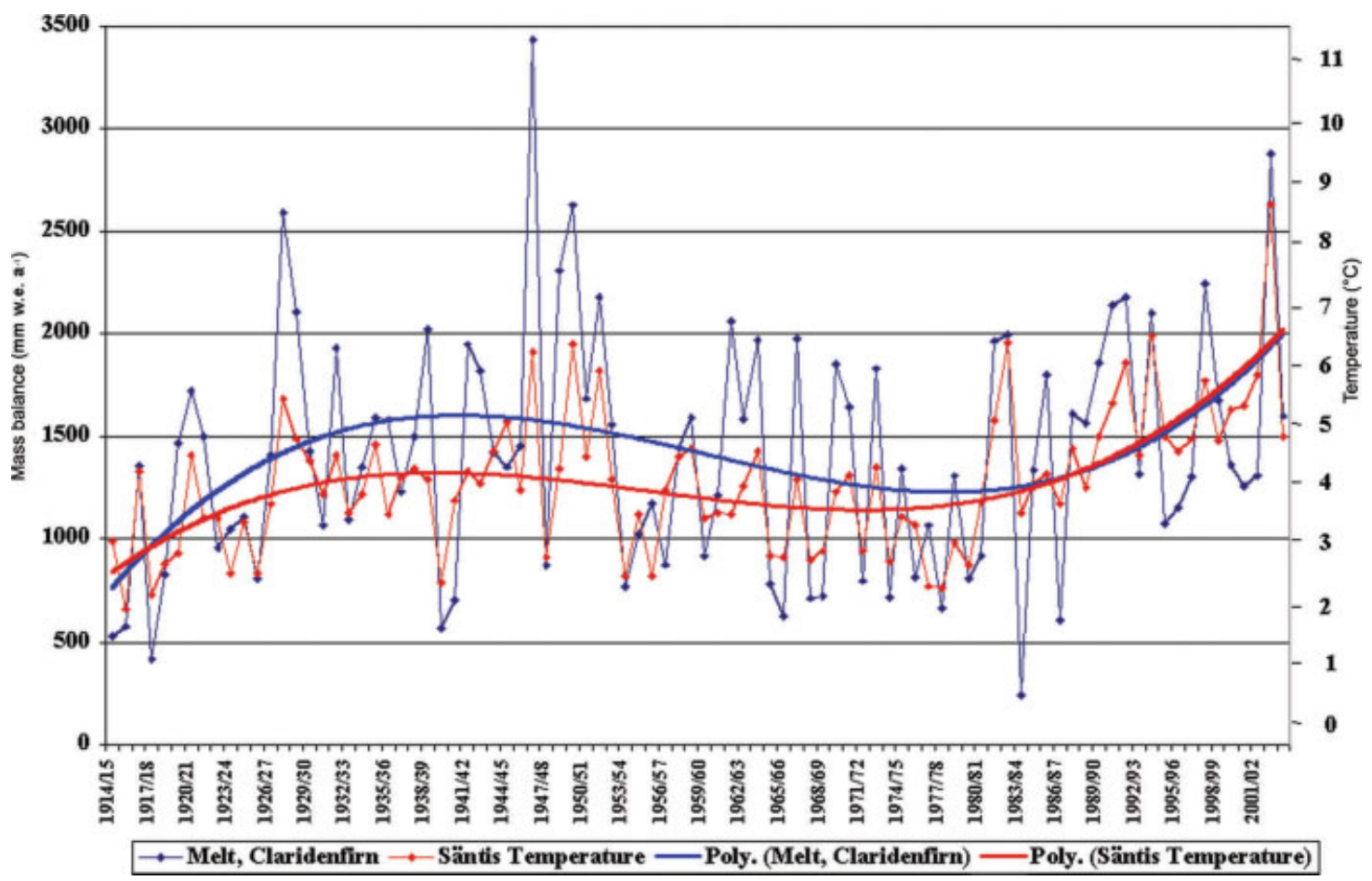

Fig. 5. Summer balance on Claridenfirn (blue line) and summer (June-August) air temperature at Säntis meteorological station (red line) for the period 1914/15-2001/02. Säntis is the oldest official high-altitude meteorological station in Switzerland, located $60 \mathrm{~km}$ due northeast from Claridenfirn at $2490 \mathrm{~m}$ a.s. I., close to the mean ELA of Claridenfirn $(2560 \mathrm{~m})$. Note that the largest melt of $3432 \mathrm{~mm}$ was observed in summer 1947, at a lower temperature $\left(6.4^{\circ} \mathrm{C}\right)$ than in the warmest recorded summer of $2003\left(2878 \mathrm{~mm}, 8.8^{\circ} \mathrm{C}\right)$.

of the acceleration of the hydrological cycle in a warmer climate. The possibility of a slight increase in global precipitation in the course of the 20th century was reported earlier, based on the analysis of long-term precipitation gauge data (New and others, 2001).

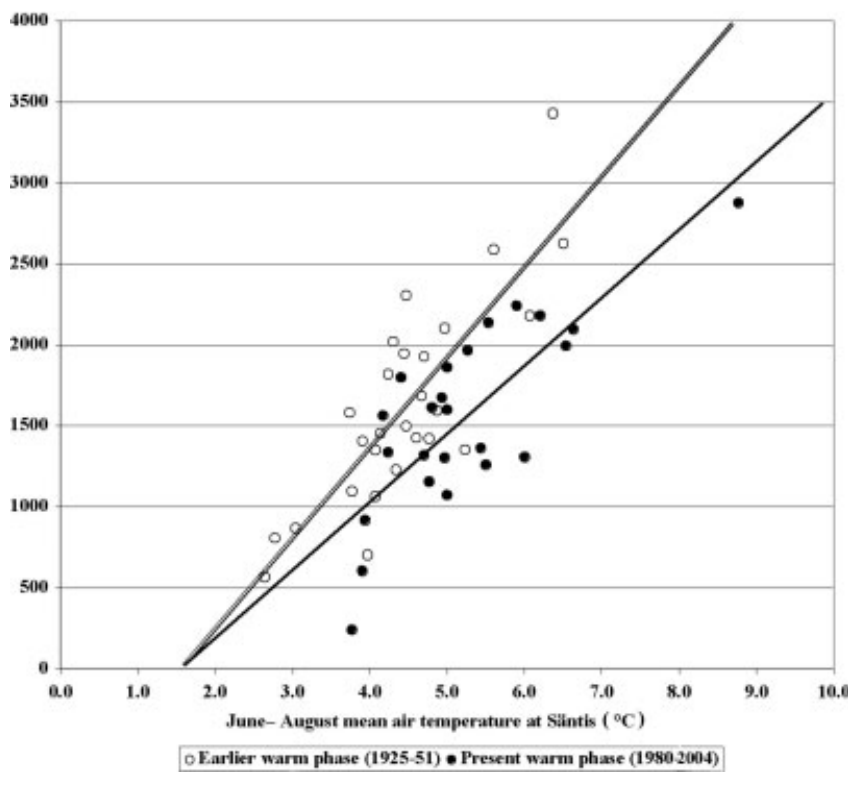

Fig. 6. Mean specific summer balance and mean summer air temperature (June-August at Säntis) for Claridenfirn for the two warm phases in the 20th century. While the melt/temperature sensitivity was $400 \mathrm{~mm} \mathrm{a}^{-1} \mathrm{~K}^{-1}$ during the earlier warm period (1925-51), it is presently (1980-2004) $320 \mathrm{~mm} \mathrm{a}^{-1} \mathrm{~K}^{-1}$.
Recently, the glaciology group of the Swiss Federal Institute of Technology (ETH), Zürich, completed the homogenization of the mass-balance series of Claridenfirn in the Glarneralpen in Switzerland. This will be the longest glacier mass-balance time series in the world and consists of winter and summer mass balances for 90 years starting with the 1914/15 mass-balance year. A part of the summer mass balance of Claridenfirn is presented in Figure 4, and displays similarity to the mean summer mass balance of the three other glaciers. The analysis of the full mass balance will be published elsewhere. The summer mass balance of Claridenfirn for the entire observation period is presented in Figure 5, together with the summer temperature (JuneAugust) at Säntis, a nearby high-altitude meteorological station. This diagram shows the relationship between the melt and temperature changes during the last 90 years. There is a change in the temperature/melt relationship between the two warm phases. During the earlier warm phase from the 1920 s to the early 1950 s, the mean melt rate was larger than during the present warm phase beginning in 1990 when compared at the same temperature. Figure 6 shows a shift in the temperature/melt relationship indicating the existence of an additional energy source for the melt during the earlier warm phase. Since this energy source is independent of temperature, it must be sought outside the sensible heat flux and longwave radiation. This leaves only solar radiation as a possible cause. The global radiation (direct solar plus diffuse-sky radiation) was considered as a necessary factor for fine tuning in the melt/temperature index method (Ohmura and others, 1992). In Figure 7 the change in global radiation during the last 60 years is presented. The figure was prepared after an intensive quality control of the four longest observation series of global radiation in western 


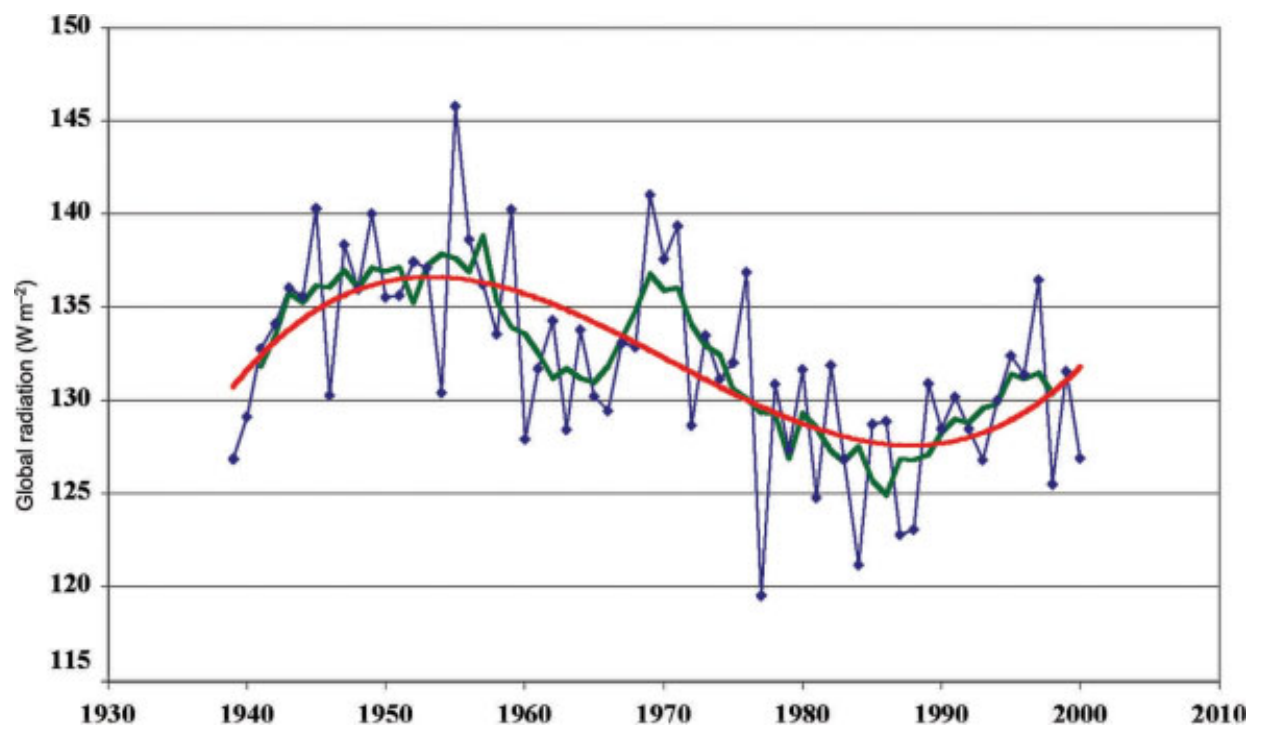

Fig. 7. Mean annual global radiation for the longest four records in Europe, Stockholm, Wageningen, Davos and Locarno-Monti, for the period 1939-2000. During the last 60 years the global radiation has undergone substantial change, peaking in the late 1950s and reaching a minimum in the mid-1980s.

Europe stored at the World Radiation Monitoring Centre in the author's institute. Global radiation was larger during the period from the 1940s to the early 1950 s by about $15 \mathrm{~W} \mathrm{~m}^{-2}$. The global radiation decreased throughout the 1960 s and 1970s. Although the global radiation started increasing in the late 1980s, it still remains well below the pre-1960 level. This phenomenon has recently been termed global dimming but has been known since the 1980s (Ohmura and Lang, 1989). The long-term fluctuation in the summer mass balance of Claridenfirn clearly demonstrates the effect of global dimming in the differential temperature/melt relationship represented in Figure 6 . The relationship shows how the solar radiation sets in as a melt factor. At lower temperatures the solar radiation has little effect on the rate of melt. As the temperature rises, the solar radiation acts increasingly as an effective melting factor. This explains how the earlier warm phase (mid-1920s to about 1950) produced more meltwater (on average, $1632 \mathrm{~mm} \mathrm{a}^{-1}$ ) at a lower temperature $\left(4.5^{\circ} \mathrm{C}\right)$ than the present warmer phase (late 1980s to present) $\left(1562 \mathrm{~mm} \mathrm{a}^{-1}\right)$ at considerably higher temperature $\left(5.2^{\circ} \mathrm{C}\right)$. The difference in melt between these two warm phases is estimated at $350 \mathrm{~mm}$ when the temperature difference is adjusted. This difference spread over 3 months is about $13 \mathrm{~W} \mathrm{~m}^{-2}$, which closely corresponds to the difference in solar radiation due to global dimming. Wild and others (2005) showed that the long-term variation in global radiation is influenced primarily by aerosol and secondarily by cloud changes which are to a great extent also induced by aerosol. The present result shows quantitatively how the aerosol variation influences the melt.

\section{CONCLUSION}

The most significant aspect of the glacier mass balance during the last 40 years of the observational period was the sustained negative mass balance $\left(-275 \mathrm{~mm} \mathrm{a}^{-1}\right)$. Further, the negative mass balance was accelerating $\left(-10 \mathrm{~mm} \mathrm{a}^{-2}\right)$, mostly affected by rapidly increasing melt $\left(-13 \mathrm{mma}^{-2}\right)$. During this period the accumulation increased only slightly $\left(+3 \mathrm{~mm} \mathrm{a}^{-2}\right)$, which was more than counterbalanced by the rapid increase in melt. This trend was intensified strongly during the last decade of the 20th century. Table 2 summarizes the area-weighted global mass balance for the last four decades of the 20th century. The global average annual mass balance for the last 40 years is $-275 \mathrm{~mm} \mathrm{a}^{-1}$, which resembles the mass balance of the 1980s. During the last decade of the 20th century, almost twice this amount $\left(-422 \mathrm{~mm} \mathrm{a}^{-1}\right)$ was lost, with a mean accelerating rate of $-17 \mathrm{~mm} \mathrm{a}^{-2}$. The contribution by mountain glaciers and ice caps for the sea-level rise is estimated at $43 \mathrm{~mm}$ during the entire 20th century.

The mechanism of the long-term change in the melt was investigated with the four longest mass-balance observation series, air temperature at a high-altitude station in the Alps and the four longest observation series of global radiation. The mass balance of the 20th century is characterized by two periods with larger melt centred around 1930-50, and the ongoing warming starting in the late 1980s. The earlier warm period produced more meltwater than the latter warm period, when observed under the same temperature. The difference of $350 \mathrm{~mm}$ melt in one summer between the two warm phases is considered to be due to the more transparent atmosphere in earlier times. The present analysis shows the influence of atmospheric aerosol on transmittance of the atmosphere and on cloud amount, and further on the global radiation at the Earth's surface. The present work proposes quantitatively the effect of the global dimming on the glacier mass balance.

Table 2. Global glacier mass balance by decades (unit in $\mathrm{mm} \mathrm{a}^{-1}$ )

\begin{tabular}{lcccc}
\hline & $\begin{array}{c}\text { Winter } \\
\text { balance }\end{array}$ & $\begin{array}{c}\text { Summer } \\
\text { balance }\end{array}$ & $\begin{array}{c}\text { Annual } \\
\text { mass balance }\end{array}$ & $\begin{array}{c}\text { Sea-level } \\
\text { contribution }\end{array}$ \\
\hline $1965 / 66-69 / 70$ & 808 & -1016 & -208 & 0.29 \\
$1970 / 71-79 / 80$ & 913 & -1104 & -191 & 0.27 \\
$1980 / 81-89 / 90$ & 954 & -1202 & -248 & 0.35 \\
$1990 / 91-1999 / 2000$ & 961 & -1383 & -422 & 0.59 \\
\hline
\end{tabular}




\section{ACKNOWLEDGEMENTS}

The author wishes to thank the following colleagues who generously provided mass-balance data still unpublished: R.J. Braithwaite (University of Manchester), L.N. Braun (Bavarian Academy of Sciences), M. Funk (ETH Zürich), G. Kappenberger (Swiss Meteorological Institute), H. Müller (Tergeso AG) and C. Vincent (University of Grenoble). The author was greatly supported by members of the World Glacier Monitoring Service, Zürich, notably by W. Haeberli (director), M. Hoelzle and M. Zemp.

\section{REFERENCES}

Braithwaite, R.J. 2002. Glacier mass balance: the first 50 years of international monitoring. Progr. Phys. Geogr., 26(1), 76-95.

Braithwaite, R.J., Y. Zhang and S.C.B. Raper. 2002. Temperature sensitivity of the mass balance of mountain glaciers and ice caps as a climatological characteristic. Z. Gletscherkd. Glazialgeol., 38(1), 35-61.

Chen, J. 1991. Changes of Alpine climate and glacier water resources. Zürcher Geogr. Schrift. 46.

Dyurgerov, M.B. and M.F. Meier. 1997. Mass balance of mountain and subpolar glaciers: a new global assessment for 1961-1990. Arct. Alp. Res., 29(4), 379-391.

Dyurgerov, M.B. and M.F. Meier. 2005. Glaciers and the changing Earth system: a 2004 snapshot. Boulder, CO, University of Colorado. Institute of Arctic and Alpine Research. (INSTAAR Occasional Paper 58.)

Dyurgerov, M., M. Meier and R. Armstrong, eds. 2002. Glacier mass balance and regime: data of measurements and analysis. Boulder, CO, University of Colorado. Institute of Arctic and Alpine Research. (INSTAAR Occasional Paper 55.)

Haeberli, W. 1985. Fluctuations of glaciers 1975-1980 (Vol. IV). Paris, International Commission on Snow and Ice of the International Association of Hydrological Sciences/UNESCO.

Haeberli, W. and M. Hoelzle. 1993. Fluctuations of glaciers 19851990 (Vol. VI). Paris, International Commission on Snow and Ice of the International Association of Hydrological Sciences/ UNESCO.

Haeberli, W. and P. Müller. 1988. Fluctuations of glaciers 19801985 (Vol. V). Paris, International Commission on Snow and Ice of the International Association of Hydrological Sciences/ UNESCO.

Haeberli, W., M. Hoelzle, S. Suter and R. Frauenfelder. 1998. Fluctuations of glaciers 1990-1995 (Vol. VII). Paris, International Commission on Snow and Ice of the International Association of Hydrological Sciences/UNESCO.

Jones, P.D., M. New, D.E. Parker, S. Martin and I.G. Rigor. 1999. Surface air temperature and its changes over the past 150 years. Rev. Geophys., 37(2), 173-199.

Kasser, P. 1967. Fluctuations of glaciers 1959-1965. A contribution to the International Hydrological Decade. Paris, International Commission of Snow and Ice of the International Association of Scientific Hydrology/UNESCO.
Kasser, P. 1973. Fluctuations of glaciers 1965-1970. Paris, International Commission on Snow and Ice of the International Association of Hydrological Sciences/UNESCO.

Kjøllmoen, B. 1998. Glasiologiske undersökelser i Norge 1996 og 1997. NVE Rapp. 20-1998.

Kjøllmoen, B. 2000. Glasiologiske undersökelser i Norge 1999. NVE Rapp. 2-2000.

Kjøllmoen, B. 2001. Glaciological investigations in Norway 2000. NVE Rapp. 1-2001.

Kjøllmoen, B. 2003. Glaciological investigations in Norway 2001. NVE Rapp. 1-2003.

Kjøllmoen, B., L.M. Andreassen, G. Elvehöy and N. Haakensen. 1999. Glasiologiske undersökelser i Norge 1998. NVE Rapp. 5-1999.

Kuhn, M.H. 2004. Die Reaktion der österreichischen Gletscher und ihres Abflusses auf Aenderungen von Temperatur und Niederschlag. Österreich. Wasser Abfallwirts., 56(1-2), 1-7.

Letréguilly, A. 1984. Bilans de masse des glaciers alpins: méthode de mesure et répartition spatio-temporelle. (PhD thesis, Université Joseph Fourier.)

Meier, M.F. 1984. Contribution of small glaciers to global sea level. Science, 226(4681), 1418-1421.

Mercer, J.H. 1967. Southern Hemisphere glacier atlas. Natick, MA, US Army Earth Sciences Laboratory. (Technical Report 67-76-ES.)

Müller, F. 1970. Guide book for 'Perennial ice and snow masses'. In Perennial ice and snow masses: a guide for compilation and assemblage of data for a world inventory. Paris, UNESCO/International Association of Scientific Hydrology, 1-23. (Technical Papers in Hydrology 1, A. 2486.)

New, M., M. Todd, M. Hulme and P. Jones. 2001. Precipitation measurements and trends in the twentieth century. Int. J. Climatol., 21(15), 1889-1922.

Oerlemans, J. 2001. Glaciers and climate change. Lisse, etc., A.A. Balkema.

Ohmura, A. 2004. Cryosphere during the twentieth century. In Sparling, J.Y. and C.J. Hawkesworth, eds. The state of the planet: frontiers and challenges in geophysics. Washington DC, American Geophysical Union, 239-257.

Ohmura, A. and H. Lang. 1989. Secular variation of global radiation in Europe. In Lenoble, J. and J.F. Geleyn, eds. IRS '88: current problems in atmospheric research. Hampton, VA, A. Deepak Publishing, 298-301.

Ohmura, A., P. Kasser and M. Funk. 1992. Climate at the equilibrium line of glaciers. J. Glaciol., 38(130), 397-411.

Ohmura, A., M. Wild and L. Bengtsson. 1996. A possible change in mass balance of Greenland and Antarctic ice sheets in the coming century. J. Climate, 9(9), 2124-2135.

Roeckner, E., L. Bengtsson, J. Feichter, J. Lelieveld and H. Rodhe. 1999. Transient climate change simulations with a coupled atmosphere-ocean GCM including the tropospheric sulfur cycle. J. Climate, 12(10), 3004-3032.

Wild, M., H. Gilgen, A. Roesch and A. Ohmura. 2005. From dimming to brightening: decadal changes in solar radiation at Earth's surface. Science, 308(5723), 847-850. 